\title{
視互協力の現 状
}

\section{植 村 弥 患子* \\ 日本歯科大学図畫館}

\section{要 約}

医学図書館協会加盟館の構成メンバーを分析し, その 規模・諸条件の格差を理解しながら協力すべき事柄の限 度をどこに置いたらよいか等を検討してはどうか。

これはあくまで試案にとどまるけれども，それぞれの 特質を生かした条件を入会加盟時点で定める。

現況に抢ける相互協力の主要部分は, 資料の貸借に負 らところが最大である。それも複写によることが現物の 貸借関係を遙かに凌駕しているが果してこのままの状態 でよいものかどうか。もう少し複写の実態にメスを入れ る必要はないか。

その他では大学の特質を生かした資料収集はどの程度 可能か。加入メンバー間での図書館の諸問題に対応出来 るリファレンサーを分野別に各地域なり, 各館に適宜対 応出来るよう配置したらどらか。

\section{は じめに}

私どもの図害馆は，相互協力を論ずるには未熟で，未 だに他館に扣世話になること大で肩身の狭い思いがして いる次第です。

しかしながら心の片隅では，いつの日か，わずかなこ とでも他館の拈役に立らたいものだと思っていることは 確です。

今日こうしてペンを取るのは余りに負担がかかりュこ の瘦身に䩒打つ思いですが，論文でなくとも結構ですと 言う扮許を頂きをしたので，理想的な四書館活動をして おられるところ, 或は当館のように牛歩の如きところ, 全国様々な条件下で活動を続けているのも事実だと思 * Yaeko, UEMURA, : Nippon Dental Callege Library.
い，現実に立脚した様々の立場の声が誌上をうめること が或意味での相互協力の土台にもなると考市えて恥を しのんでペンを取った次第です。

\section{“笛吹けど”}

以前から医学図畫館協会の総会に秥いて様々な方々が 種々の方面にわたり相互協力を叫んで久しい。

記憶にとどめておるだけでも学術雑誌の分担購入(読) 案,

二次資料の共同購入による迅速性と廉価性，或は各館 に蓄積された利用頻度の低い資料の共同保存案，これは 協会で必要部数を定めて国の助力を得て保存館（仮称） を設置したい等々提案はあった。

しかしそれ以後これらはどのような経過を辿っている かさだかでない。

提案されたことは全くもって時代に即応した必要性を 各々包含した問題であるにもかかわらず，その実行に到 るまでの道は険阻である。この難関は何に基因するのだ ろらかと言う諭議はあまりなされていない。そして総会 に提案されたこともその次の年までどれだけ多くの人の 記憶に残っているのだろらか。ましてや翌年も翌々年も 議論を煮つめると言うような経験も鿒聞にしてない。

浅学な見解ではあるが一応加盟メンバーにスポットを あててみたら何かが㽞めるのではないだろらか。

\section{相貸関係の現況}

表（1）が示すように医学は当然䔩成上重要な\%を占 めているがこれらのメンバーがどの程度の相互関連作用 をしているかも再検討してみよう。 先ず第一に 1973 年度加盟館統計表の中から観 察して 
加盟メンバー構成 表 (1) (1973 加盟館統計より)

\begin{tabular}{|c|c|c|c|c|c|c|c|}
\hline 項目 種別 & 大学 & 究の & 計 & 国立 & 公立 & 私立 & $\begin{array}{l}\text { その } \\
\text { 他 }\end{array}$ \\
\hline 加 盟 数 & 55 & 13 & 68 & 24 & 10 & 21 & 13 \\
\hline 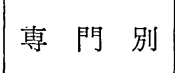 & 医学 & 歯学 & $\begin{array}{l}\text { 保健 } \\
\text { 衛生 }\end{array}$ & 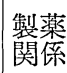 & $\begin{array}{l}\text { 癌関 } \\
\text { 係 }\end{array}$ & $\begin{array}{l}\text { 原爆 } \\
\text { 関 }\end{array}$ & 他 \\
\hline 加 盟 数 & 46 & 7 & 2 & 3 & 2 & 1 & 7 \\
\hline
\end{tabular}

相互貸借関係
表 (2)
限りでは 15 メバーとなっている。

常日頃この 15 メバーにウェイトがかかっているの であろらか。この 15 メンドーの地域を追跡してみた。

北海道地域 2 メンバー, 東北地域 1 メンバー, 信 越地域 1 メンバー, 中部地域 1 メンバー, 関東地域 4 メンバー, 阪神地域 5 メンバー, 中国地域 1 メン バーといら結果である。四国，九州地域は見当らなかっ た。勿論この一年間だけの数字では，何とも言えないこ とであるがこうしてみると日本列島に或一個所だけの集 中とも見受けられずむしろ偶然の結果であるにせよ，平

\begin{tabular}{|c|c|c|c|c|c|c|c|c|c|}
\hline & & $\begin{array}{l}\text { 歯科橍 } \\
\text { 数 }\end{array}$ & $\begin{array}{l}\text { メンバ } \\
\text { - 数 }\end{array}$ & 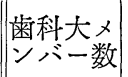 & & 総 数 & メ & 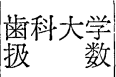 & 慗大メy \\
\hline 現 物 貸 出 & 5,537 & (66) & 50 & (5) & 複写貸与 & 139,565 & 67 & $(3,575)$ & (6) \\
\hline 現 物 借 受 & 4,104 & (308) & 49 & (4) & 複 写 借 受 & 82,091 & 68 & $(4,189)$ & (7) \\
\hline 差 & 1,433 & & & & 差 & 57,474 & & & \\
\hline
\end{tabular}

みると表 (2) の通りである。

現物に関して扱い数は, 複写に比較したら貸・借共に 10\%にも充たないから余り問題はないと思うけれど，そ れでも貸借の差引で 1,433 と言う数はどんな意味がある のだろう。加盟メンバーでない所からの依頼数なのだろ らか? 同様に複写の方に和いては, 57,474 と言う数字 は, 加盟メンバーの借受数の $70 \%$ に相当するこの実体 はどうであろうか。この加盟館統計では加盟メンバー外 からの依頼と言う項目がなかったけれど，単純にメンバ 一同志の数から差引いた残りはメンバー外と見てもよい のだろらかといら疑問も起こって来る。

ともあれ，協会メンバーに対する需要がどこかの分野 で高まって来ていることは確実のようだ。

メンバー間でも現物の貸借に関してどちらも 0 件数と いうメンバーは10メンバーしかないけれども，複写に 関しては, 貸借どちらも0といらメンバーは皆無であっ た。それは事程左様に必要性の高さを物語っていること は言をまたない。

いま少し分析してみると, 現物における貸出の優位メ ンバーは 24 館, 借受の方が多いメンバーは 43 館, 貸借 同数といらのは 1 メンバーである。一方複写の方では, 複写応諾の多いメンバーは 29 館, 複写依頼が多いメン バーは 39 館であり, 現物及び複写の分野どちらも他メ ンバーに資料を提供しているのは, 73 年度の統計に見る
均的な距離を得て資料が収集されているメンバーがある のか，この一年間たまたま，需供の関係がこの平均的な 現象を発生させたのかは解らない。ともあれ，もし $1 x$ ンバーにのみ多大な負担がかかり過ぎているとすれば, それが何であるかを各館が分析しようという努力はすべ きである。分析してみると存外ささやかなことで解決出 来るものもあるいはあるかもしれない。只相互協力の団 体であるから大いに活動がなされて然るべきだけれど も, 一方的に片寄った貸借関係が長期間継続すると, 結 果的には余りよくない事態にもなりかねない。

\section{相貸関係のバランス}

そこで相貸関係のバランスをどのよらにしたららまく 保持して行くことが出来るかも各館考慮に入れねばなら ないことの要素になる。先ず考えられることは, 需要と 供給の関係である。研究の流れというようなものもあ り, ある年には癌関係の研究がかなりな資料を要求し, 又違う年には，公害関係に多くの資料を求められると言 らように時代に即応した研究の流れがあることは事実で あるが，ぞこの大学図書館でも全領域の資料をカバーす ることは経済的にも物理的の面からいっても不可能な ことは明らかである。利用効率からいっても，もら少し 考慮した資料の収集方法を皆して考えてゆくべきではな いだろらか。それには，各館に特色を持たせた資料収集 
を分担させることではないだろらか。医学図書館協会加 入時の規制の中にその大学に特色を保持した資料を必ら ず何誌か入れておくと言うようにしたら全国的に均衡の とれた相貸関係の資料が平等に保持していると言うこと になる。

研究者の研究傾向は年と共に変わるにしても，一応自 分の大学の図書館には，X資料ならば他からの要望には 応じられるといら自信も出て来るのではないだろらか。

現在では各館の歴史的収集結果を自館の要望で撰択し て入手している状況であるが，果して前述している各種 の構成メンバーがどこにもあるような資料を持つ必要性 がぞの程度あるかを検討すべきである。

勿論最低限必要な資料の具備は別としての話である。 大学の性格により余り必要性のない上うな資料むあるい はタイトル数の規制等で購読をよぎなくしているところ はないのだろらか。そして何処にでもあるものはあって 必要としているものはどこにもないというのでは，相互 貸借の意義はなくなるのではないのだろらか。

机上のソロバンで一笑に付されるだろらけれど，1973 年加盟館統計の図書購入費中 (b) 䧴誌の図書館購入総額 は 646,872,000 円である (加盟 68 メンバー) 単純に 1 館当りの平均值を出したところ，9，512，820 円位にな る。勿論この平均值にはバックナンバーの支払額も含ま れているので, 正確なその年度の雑誌予算額とのかかわ り合いは，いえないけれども仮に 9,512千円が平均值 としたらその $1 \%$ 負担位で（646万円）内外合せての雑 誌が何誌購読出来るか等の試算をしてみてもいいのでは ないだろらか？ 少なくとも 150 誌余は購読出来るので はないだろらか。そして現物は各館で割当られた（と言 っても話し合いの上で大学の特性に合わせた）雑誌を管 理して行くことも可能ではないだろらか？

これはあくまで私案であるがそうすれば管理上もきち んとするようになる。各館にその負担が平均された誌数 が保有されることは物質的に有意な立場だけの評価はな くなる。利用度の高い低いは別としても負担率が同じで あると言らことは, メンバーの結束を平等にして有意義 にするのではないだろらか。

これは雑誌の分担購入といらことになるかもしれない が，メンバー構成が国，公，私立大学の他，民間とそれ ぞれ性格を異にすることを考虑に入れれば全面的な变革 にはならず経済的にも $1 \%$ 金額相当でしかも現物は自館 に保管されることならそら難解なことではないのではな いだろらか?
私ども歯科大学図書館から相貸関係をみると，先ず他 大学関係機関に扣世話になることが多いのではなはだ肩 身が狭い思いをする。構成割合からしても知れたもので ある。昭和 43 年大学に歯学部設置のあったものは，国 立 7 , 公立 1 , 私立 7 大学であった。昭和 49 年全国大 学一覧によると国立，公立には変化なく私立で 15 と約 倍の増設がみられる。増加したところ必らずしも未だ加 盟しているとは限らす゚この点でも当校としても新潟歯学 部の増設の関係上大いに関心がある。多分関係機関に打 世話になっていることと推察する。

ただ崡科関係の研究者の資料の利用状況をみると，他 科領域の資料にも触れながら研究を進めているようであ るが，果して歯科以外の医学研究者は，歯科関係との関 連的な研究をどの程度されているか定かでない。従って 資料の相貸関係も自づと歯科関係者が他科領域の資料を 求める事の方が，歯科以外の医学関係者から歯科関連分 野の資料を求められることは稀な状況である。つまり可 逆関係はどうも現状では成立不可能なように思えるが， 歯科大学関係に执いては大分数も增えたことであるから より一層特色ある資料の収集で相互関係を密にして行っ たらよいと思う。

それには歯科大学図書館関係者の集りをるって医学図 書館協会の中に占める蒾科大学图書館の位置などを皆し て話し合って行くべきではないだろらか？

開設者別歯科診療所の推移

\begin{tabular}{|c|c|c|c|c|c|c|}
\hline 年 & 総 数 & 国 & 公的 & $\mid$\begin{tabular}{|l} 
社会保險 \\
$\mid$ 関団体
\end{tabular} & 会社 & 私 的 \\
\hline $\mathrm{S}_{43}$ & 29.489 & 6 & 54 & 25 & 49 & 29.355 \\
\hline 44 & 29,649 & 7 & 47 & 30 & 44 & 29,521 \\
\hline 45 & 29,911 & 11 & 56 & 24 & 42 & 29,778 \\
\hline
\end{tabular}

上記の表は昭和 46 年度厚生白書によるものだがそこ からも解ると招り蒾科診療所は昭和 45 年末で 29,111 施 設あり毎年 200 300 ケ所増加している。

開設者の推移は私的診療所の数が圧倒的に多い。これ は, 国, 公立大学卒業の歯科医の数は知れたもので私大 卒の歯科医が開設している数が圧倒的なことを物語って いる。これらの人々への資料提供は余りにも少ない。現 状の医療制度の中で臨床医にどれだけの研究時間が持て るかは問題であるが，学内者のサービスにとどまらずも っと広域的なサービスも行われることも必要ではないだ ろらか。 


\section{館員のための相互協力}

いままで述べたところは，主に利用者のための物質的 な相互協力に基づいたものであるが，果して利用者のた めばかりの相互協力にとどまっていていいものであるう か。物質的なことは,その大学の財政的なことに重要な関 係も㐫図書館のみでどうる解決出来ることばかりでは ないこともあり得るから，資料の多少でのみ協力の度合 を推量することは避けたい。そんな意味でも前述のょう な均等な割合での参加を提案したのだが物質的な面だけ でなく知識の上での相互協力を図書館同志で行うことも 私は重要な相互協力だと思っている。各々各館の捄役に 少しでも立てるような経験・体験・知識の交流・交換を 個人的な知已の範囲でなく公的にメンバー館ならば誰で も門を吒けるような体制作りをしては如何であるうか？

図書館に関する諸問題を出来るだけ多くのメンバーに 専門を一つザつでも与えて， $\times \times$ の問題は $\times \times$ 図書館の 某氏に一応相談を持って行くことが出来るというように ならないものだろらか。勿論すぐにということではなく 徐々に協会の活動自体がその上らに動いて行ったらどん なに解決の糸口が早く得られるのではなかららか。

利用者のためには，どの館も，もっとこうして西げよ うとかこんな面でも工夫しょう等とあらゆる面からの検 討をしていると思うけれぞ，自分達の仕事に関しては， 公的に協会といら性格をぞれ程フルに利用しているだる らか。個人的に親交のある人，或は地域的に近いといら ことでの交流は山るかもしれないけれど，もっと協会員 としての交流を考慮する必要がありはしないだろうか？ 具体的に一，二例をあげれば，小さな問題であっても， 一応整理汇関しての諸問題は, 某大学, 図書館建築に闑 しての照明に関しては某大学の某氏といらょうに館員の ためのリファレンサーを各地域なり或は加盟メンバーに 分担担当させる体制を作っていったら協会の水準という ものが自然と一定のレベルになるのではないだろらか。 勿論, 協会主催の研究集会もかなりの成果を上げてはい る筈であるが，日々解決出来るような事柄もある筈であ る。公共図書館が行っている利用者のためのリファレン スのようなものを自分達のために行ったら，基本的には 各館まちまちと言うようなものが，少しずつでも標準化 されていくのではないだろらか。

あるいは私立大学図書館協会で行われているような分 科会のようなるのを持つか, 持つと同時隹絟豊富な館 員にリファレンスしてもらえる体制を協会として作り，
多少なりとも 68 加盟館が知的サービスを受けられるシ ステムを皆して考えて物質的な面ばかりでない相互協力 の平等負担をして行くことも一つの方向ではないだろ らか。

諸外国はどうか，私は余り見聞が広くなくて知らない が，日本の図書館の発達過程はどうもアメリカ的な要素 を多分に吸収していて資料の量的価值判断をする傾向に あるようだけれど，一応顧文て果して利用者のためばか りでなく，館員のためにどれだけの協力体制をとってい るかといらことが，ひいては利用者に還元することにな るのではないだろらか。’73 年度図書館統計が物語る図 書館員の数と年間図書購入額等を比較してみると, 活動 状況までも如実に想像出来るような気もする。諸々の条 件下で頑張る館員，理想的な条件下で働ける館員様々で あるけれども，出来るだけ格差を少なくして同等で交流 の出来る素地を作ることに協会の意義があるのではない だろらか？

日本医学図書館協会相互貸借規約 (2) 飞よれば，「相互 貸借は加盟館の好意と特典であるが権利ではない。」と してあるが，この表現に含まれる意味は味わい深いもの である。物質的な資料の貸借関係についてあくまで好意 でしてもらう，して差し上げると言う関係は，余り現代 的なむのでない感じである。我々はその好意をスムーズ に行うために平等に義務として各館からカレント誌及び 洋書の增加状況等を報告している筈である。一方で権利 ではないと表現し他方で好意遂行のために義務を果すと 言うのは少しロジッグが合わない気がする。日常的には 相互貸借関係はそれが好意でなされていると言う観念に もとづいて仕事はしているだろらか？むしろ協会に加 盟していたら当然といった考えで目録から相手館を探し ては往復はがきに打字しているのが現状ではないだろう か。

図書館間の協力ということに格差がないよらに同等の 立場で対応出来るようにしたいものである。それには， 出来る限り負担率が平等になされるような協会員の配慮 がなされるべきである。

図書館の協力について「専門図書館のための資料の整 理と運用」の中にふれている。組織的にするのが困難で あれば個々にでもよい。ともかく，連けいをるとめ，図 書館員相互に協力し合う気運をもたなくてはならないの である。図書館の協力を具体的に㔖げていた。

1）個々に出来るもの

(a)※資料の相互利用 
(b)※複写のサービス

(c)※資料の所在を教えるサービス

(d) $\triangle$ レファレンス質問に答えるサービス

(e)※資料の交換

(f) 二次資料の共同作成

2）組織的な協力体制として

(a) ※相互貸借制度

(b)※総合目録の編篹

(c) 資料の共同購入，あるいは分担収集についての 協力

(d) $\triangle$ 中央整理制度 目録カード作成, ブックカード の插入, ラベル貼付などは中央館で一括して行っ て個々の図書館での整理業務を最少限にする。

（e）標準化 書誌の記述法, 図書館用品の標準化, 分類・目録・件名の標準化など

(f) $\triangle$ 図書館内の組織の確立から出発して, 図書館間 の（地域的にあるい館種別になどいろいろなア スペクトがあるが) 組織網をつくること。

いま医学図書館協会のメンバーで前記の中で実行して いるものに※印，全メンバーではないがしているものに 印をしてみると，全然なされていない項目もあるのに 気付く。そしてこの他にこれらの項目の土台となる館員 のためのリファレンスが各人メンバー館から撰択されて 出来ればと重ねて望む次第である。

最後につたない一文ではなはだ申し訳ないが，あえて
現実から目をそらすことなく，高い理想を追らことも必 要, 又きびしい現実の中に蚉動する幾多の図書館もあっ て共存していることを拉いに理解することも大切な協 力の要素ではないだろらか。常に標準がどの辺に置かれ るかを客観的に判断しないと只規模の大小でのみ，云々 されるよらな時代でもあるまい。

規模に大・小差異のあることはま妨れられない事実 なのだから，むしろその水準化を均一にしょうという方 向に持っていくことこそ協力の発展を促す原動力になる のではないだろらか。それは発展途上国に対する先進国 の対処の仕方にも似ている面があるように思劣る。

やはり様々な点で優位性のある館は, 少しでもその知 識なり経験を他館のためにも公的にサービス出来るよう な体制作りを皆して徐々にでも作ってゆきたいものであ る。

まとまりのない私的見解の羅列で恥しいけれど，実感 を思いつくままに記してみた。

\section{参 考 文 献}

1）第 44 次日本医学図書館協会加盟館統計 JMLA

2) 昭和 49 年度全国大学一覧 文部省大学局大学課監修

3）昭和 46 年度厚生白書 厚生省

4）専門図書館のための資料の整理と運用 社団法人 日本図書館協会 1967 年

\section{国内ニュース}

\section{著作権審議会第 4 小委員会 (複写複製)の発足}

最近ゼロックス等複写複製手段の発達・普及はめざま しく, これに伴う著作権問題の検討の必要性が指摘さ れ，また，国際的にも精力的に検討が行われている状況 にかんがみ，このたび著作権審議会に第 4 小委員会を設 け，複写複製に関する著作権問題の審議を行うこととな った。昭和 49 年 7 月 10 日に第 1 回の会合が行われ, 委 員は, 図書館, 法学界, 出版界, 複写機器業界の代表 18 名で構成されている。

すでに，無断複写が重大な著作権侵害をひき起してお り, 学術や文化の正常な発展のためには, 放置しておけ ないといら認識については, 全委員が共通の理解に立っ ているようである。問題は, 利用者, 著作権所有者相方 が無断複製の実態について正確なデータを持っていない

\section{東.西南 北}

ことと，解決のための有効な方法がつかみにくいことで あろう。委員の 1 人で雑誌 UP 編集子の $\mathrm{M}$ 氏は次のよう に述べている。我々がいまなすべきは，第一に被害の害 態をつかむこと，第二に外国ですでに試みられている解 決法の実際を学ぶことだ。最後は著作権法の問題に帰着 するわけだが，現行法の解釈論議や抜け道探しに迷い込 むことなく，現実の問題を解決するためにはいかなる修 正が必要かを求める, 建設的な審議でありたいと思う。」

な拈，第 1 小委員会は条約関係を扱引。第 2 , 第 3 小 委員会は昭和 47 年 3 月に設けられ，それぞれコンピュ 一タ及びビデオに関する著作権問題が審議され, 48 年 6 月及び 3 月にその報告が行われている。

（文化庁文化部著作権課 : 著作権審 㵪会第 4 小委員 会の発足について：昭和 49 年 7 月 8 日付印刷物及 び委員名簿) (UP 3(9)：34，1974.) 